\title{
Pyritized Chuaria-Tawuia from the Pre-Ediacaran Samria Shale, Upper Vindhyans, Rajasthan: An Indication of Anaerobic Environmental Conditions
}

\author{
Srivastava $\mathrm{P}^{*}$ \\ Centre of Advanced Study in Geology, Lucknow University, Lucknow, India
}

*Corresponding author: Purnima Srivastava, Centre of Advanced Study in Geology, Lucknow University, Lucknow, 226020, India, Email: purnimasrivastava_51@rediffmail.comossils

\section{Research Article}

Volume 3 Issue 1

Received Date: April 15, 2020

Published Date: August 11, 2020

\section{Abstract}

The paper records carbonaceous megafossils assignable to pre-Ediacaran age from a new horizon, Samria Shale, Bhander Group, Upper Vindhyans, Bundi district, Rajasthan. The assemblage is represented by Pyritized Chuaria and Tawuia with equally good morphological details like excystment structures, suggesting their resistant vesicles and eukaryotic affinity. In addition, the assemblage also comprises multicellular metaphytes. Pyritized fossils indicate almost anaerobic environmental condition, rapid burial of organisms under ocean sediment and small amount of decaying bacteria. Pyritization also indicate the presence of sulphur reducing bacteria and dissolved iron at the time of fossilization. Present assemblage is represented by Chuaria circularis, Tawuia dalensis, Ellipsophysa sp., Eopalmaria prinstina, Tuanshanzia lanceolata or Changchengia stipitata, Longfengshania sp. and Proterotainia montana. Two unidentified fossils forms informally described as Form ' $\mathrm{A}$ ' and ' $\mathrm{B}$ '. An unusual and rarely reported process of fossil pyritization has been observed in present assemblage.

Keywords: Carbonaceous Megafossils; Ediacaran Fossils; Morphological

\section{Introduction}

The Vindhyan Super group has been globally acknowledged as one of the best repository for the Proterozoic life evidences. It has now been supported by reports on carbonaceous megafossils, Ediacaran fossils, microbial mats and microfossils. Age of the Super group has long been a matter of debate, but substantial data has been generated in last two decades, regarding the dates and fossil assemblages (both micro and megafossils). These fossils are well preserved and exhibit extensive diversity. Present paper reports multicellular metaphytes from a new stratigraphic unit of Bhander Group, Samria Shale, well exposed in Bundi district of Rajasthan.

The emergence of megascopic multicellular organisms is a significant event in the Proterozoic evolutionary palaeobiology. Before the appearance of the Edacaran fauna, the biosphere was dominated by primitive metaphytes and different kinds of microscopic organisms. These early organisms started photosynthesis and released oxygen, thus created an oxygenated environment for the emergence of Ediacaran organisms.

\section{Geological Setting}

The Vindhyan Super group occupies large area in Central India, stretching from Bihar to Rajasthan. It attains a huge thickness of more than 4000 meters and a vast area of about 104,000square kilometers. The dominant lithology is represented by sandstone, shale, porcellanites, conglomerates, limestones and dolomites. The Super group has been subdivided into four groups. In stratigraphic order these are; Semri, Kaimur, Rewa and Bhander groups. Except Kaimur Group, all three groups are now found to be fossiliferous. Ediacaran fossils have already been reported 
Srivastava P from the Bundi Hill Sandstone of the Bhander Group. Stratigraphically overlying the Samria Shale (Table 1). It is therefore logical to get pre-Ediacaran metaphytes and metazoans from the horizon lying below the Ediacaran fossil bearing horizon. The Samria Shale, on which present study is based, overlies the Lakheri Limestone and is overlain by the Bundi Hill Sandstone [1]. Considered the Samria Shale as a thinned equivalent to the Sirbu Shale, Prasad B, et al. [2] described it as a shale horizon overlying the non stromatolitic Lakheri Limestone and overlain by the Bundi Hill Sandstone.

\begin{tabular}{|c|c|}
\hline \multicolumn{2}{|c|}{$\begin{array}{l}\text { Generalised Lithostratigraphy of the Vindhyan Super } \\
\text { group }\end{array}$} \\
\hline \multirow{8}{*}{ Bhander group } & Dholpura Shale \\
\hline & Balwan Limestone \\
\hline & $\begin{array}{l}\text { Maihar Sandstone/Upper Bhander } \\
\text { sandstone }\end{array}$ \\
\hline & Sirbu Shale \\
\hline & Bundi Hill Sandstone \\
\hline & Samria Shale \\
\hline & $\begin{array}{l}\text { Lakheri Limestone/Bhander } \\
\text { Liemstone }\end{array}$ \\
\hline & Ganurgarh shale \\
\hline \multirow{4}{*}{ Rew A Group } & Upper Rewa Sandstone \\
\hline & Jhiri Shale \\
\hline & Lower Rewa Sandstne \\
\hline & Panna Shale \\
\hline \multirow{6}{*}{ Kaimur Group } & Dhandraul Quartzite \\
\hline & Scarp Sandstones and Conglomerate \\
\hline & Bijaigarh Shale \\
\hline & Susnai Breccia \\
\hline & Upper Quartzite \\
\hline & Lower Quartzite \\
\hline \multicolumn{2}{|r|}{ Unconformity } \\
\hline \multirow{5}{*}{ Semri Group } & Rohts Formation \\
\hline & Kheinjua Formation \\
\hline & Porcellanite Formation \\
\hline & Kajrahat limestone \\
\hline & Basal Formation \\
\hline \multicolumn{2}{|r|}{ Unconformity } \\
\hline Bijawar Group & Physllites \\
\hline
\end{tabular}

Table1: Lithostratigraphy of the Vindhyan Super group.

\section{Sample Location}

The fossiliferous shale horizon from where the samples have been collected is well exposed on way from Bundi to
Indergarh, near Rajwas village (Figure 1). A ridge of about 50 meters height comprises Lakheri Limestone, which is grey in colour. It is overlain by the Samria Shale and comprising stromatolitic limestone and fossiliferous olive green coloured shale respectively (Figure 2).

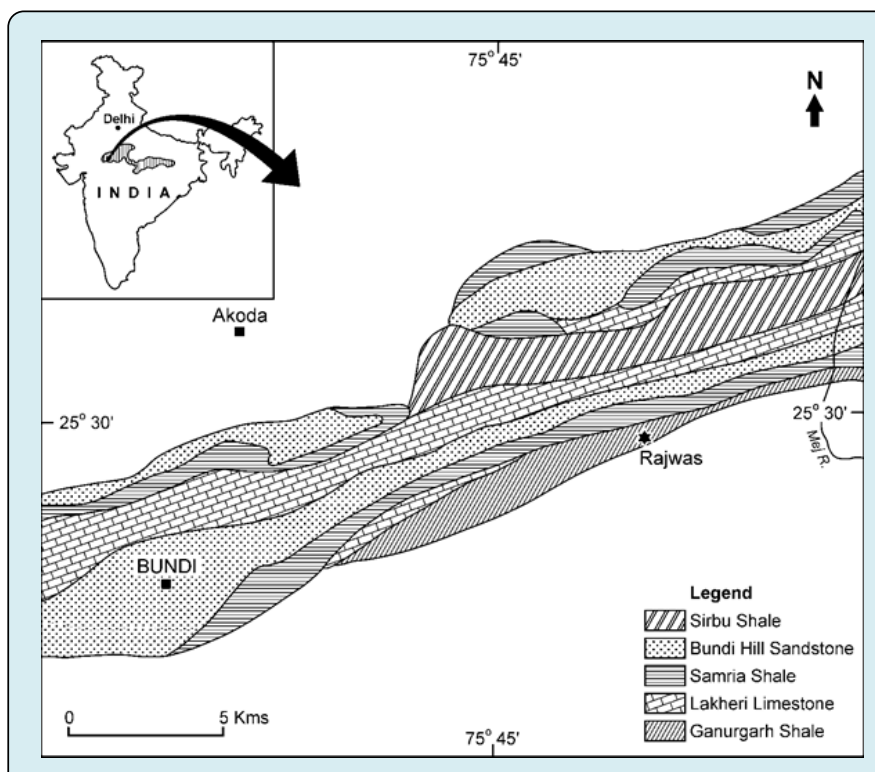

Figure 1: Geological map of study area showing sample location of carbonaceous fossil bearing shale horizon, modified after Prasad, 1984.

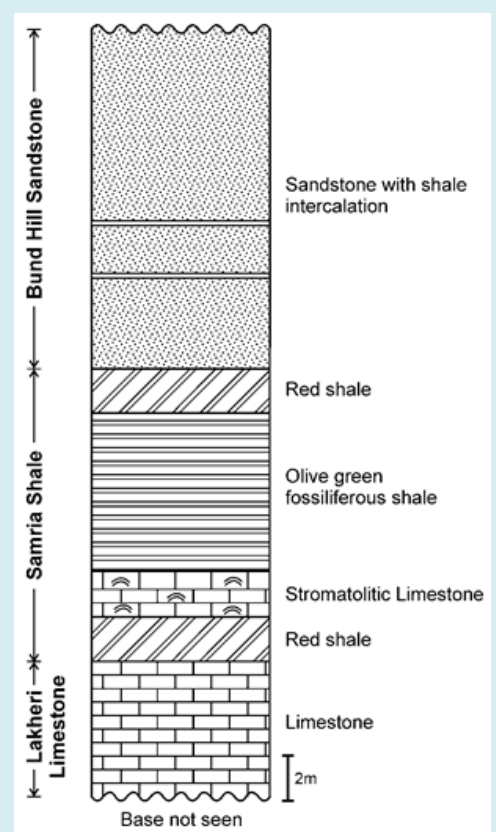

Figure 2: Lithostratigraphy of the Samria Shale, Bhander Group, Upper Vindhyans in study area, showing sample location of fossil bearing horizon. 


\section{International Journal of Paleobiology \& Paleontology}

Carbonaceous megafossils are exceptionally well preserved and moderately diversified. GPS value for fossil bearing horizon is $\mathrm{N} 25^{\circ} 29^{\prime} 41,364^{\prime \prime}, \mathrm{E} 75^{\circ} 47^{\prime} .458^{\prime \prime}$. The olive green coloured fossiliferous shale horizon is lying between two unfossiliferous reddish brown coloured shale beds.

\section{Methodology}

Samples have been collected from field and packed (with proper numbering) carefully in cotton as shale is very delicate and fragile. In laboratory the shale partings, comprising fossils have been studied in hand specimens as well as under the microscope.

\section{Carbonaceous Megafossil Assemblage}

In present assemblage, carbonaceous megafossils exhibit a wide size range from $0.3 \mathrm{~mm}$ to $7 \mathrm{~mm}$. Chuaria circularis, Tawuia dalensis, and other forms identified as Ellipsophysa sp., Eopalmaria prinstina, Tuanshanzia lanceolata or Changchengia stipitata, Longfengshania sp. and Proterotainia Montana. Two unidentified forms have also been informally described.

According to Hofmann, et al. [3], Chuaria and Tawuia genera can be considered as potential chronobiostratigraphic markers, ranging in age from $1.1 \mathrm{Ga}$ to 0.7Ga. However, in Vindhyan Super group, Chuaria- Tawuia assemblage has been reported Srivastava, et al. [4] from the Chorhat Sandstone Formation (age $\sim 1600 \mathrm{Ma}$ ) and Suket Shale Formations (age 1000 Ma) of Semri Group [5], Lower Vindhyans and Sirbu Shale and Dholpura Shale Kumar S, et al. [6] respectively which are considered to be of Ediacaran or Vendian age. Pre-Ediacaran radiation of phytoplanktons and a number of new morphologies are the most conspicuous biotic event of Precambrian. An extensive morphological variation can be noticed among Chuaria specimens of the present assemblage. It occurs with folds and wrinkles (Figures 3B-D; Figure 4F), with an enveloping sheath (Figure 3B); with or without intracellular mass (Figure 4E). Considering the morphological variation, it can be inferred that different morphologies may belong to different biological affinities. At the same time their taphonomic variations cannot be ruled out [7], compared Chuaria with Nostoc ball of Chlorophycean affinity.

Pyritized Chuarids (Figure 3B-D; Figure 4E-F) and a single specimen of pyritized Tawuia (Figure 3E) has also been recorded from the present assemblage. Soft tissue pyritization is extremely rare in fossil records, especially in Precambrian. Two main factors ensure the successful pyritizaion of fossils; one is rapid burial controlled by secular storm deposition and the other is per mineralization achieved by sufficient supply of available iron from sediments. It is inferred that under unique geochemical conditions, iron supplied covers or replaces organism, transforming them into fossils with a gold like lustier. Studies indicate that rapid burial of organism under ocean sediment (low in organic material) and very small amount of decaying material like bacteria, resulting in pyritized fossil forms. Sea water was very low in dissolved oxygen or it was anaerobic condition at the time of fossils preservation. It was explained that very little decay occurred in organism before the fossilization process began. Pre-requisite for pyritization to occur is to have large number of sulphide reducing bacteria (which live in oxygen deficient water) and high concentration of reactive iron. The bacteria change the sulphate into sulphide and can diffuse with iron [8].

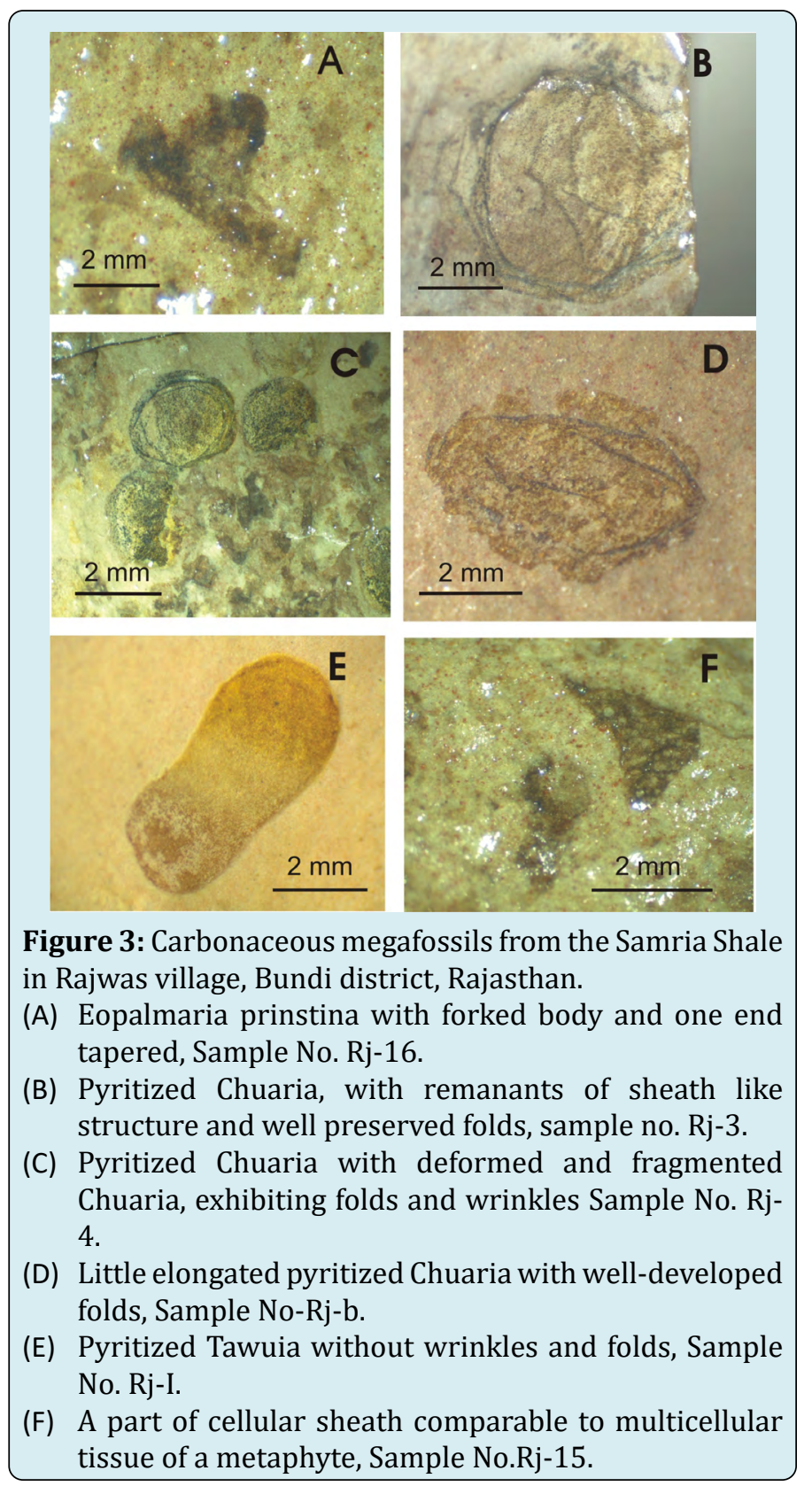




\section{International Journal of Paleobiology \& Paleontology}

Pyritized Chuarids with equally good morphological preservation indicate presence of resistant vesicle and excystment structures, suggesting their eukaryotic affinity [8]. According to scientists, there is some taxonomic control over the precipitation of authigenic minerals during early diagenesis [9]. Organic preservation is limited to certain decay resistant structures. Detailed study indicates that early digenetic mineralization such as phosphatization and pyritization played key role in the preservation of nonmineralized organisms. Pyritization is supposed to be the most important process by which no mineralizing organisms preserve in exceptional condition.
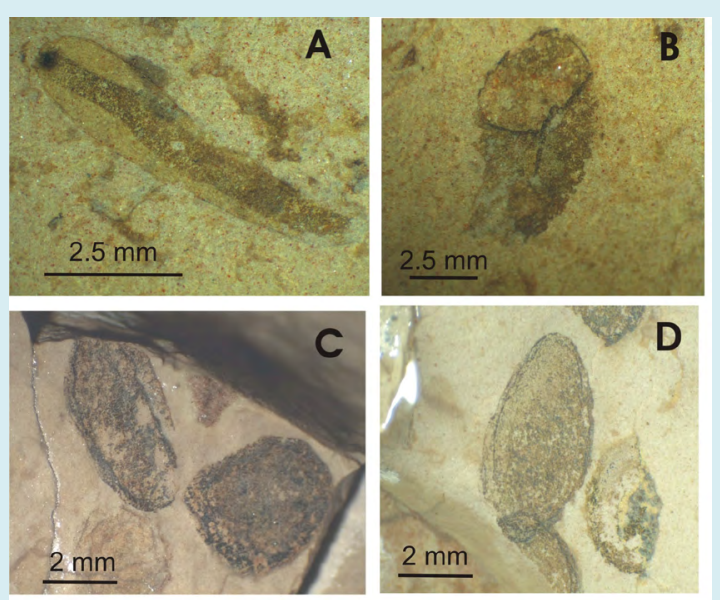

E
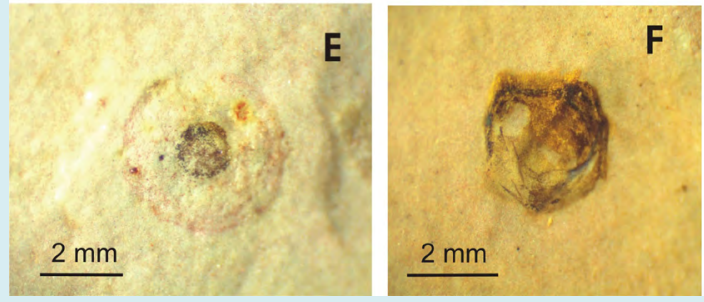

Figure 4: Carbonaceous megafossils from the Samria Shale in Rajwas village, Bundi district, Rajasthan.

(A) Possible metazoan fossil with median gut or trichome like structure and a mouth like opening at broader end, Sample No.Rj-1

(B) Cone like unidentified form with a well preserved rim in continuation, a loop like structure of same width, Sample No.Rj-1.

(C) Ellipsophysa sp. / Glossophyton and deformed, fragmented Chuaria circularis with Sample No. Rj-8 (25x3.2), Rj- 6 (25x3.2) respectively.

(D) Ellipsophysa sp. / Glossophyton and deformed, fragmented Chuaria circularis with Sample No. Rj-8 (25x3.2), Rj- 6 (25x3.2) respectively.

(E) Chuaria circularis with well-preserved intracellular mass. Sample No.Rj- I $(25 \times 4)$.

(F) Heart shaped body of a pyritized Chuaria like morphology with two furrows like structures, Sample No.Rj- 2 (25x3.5).
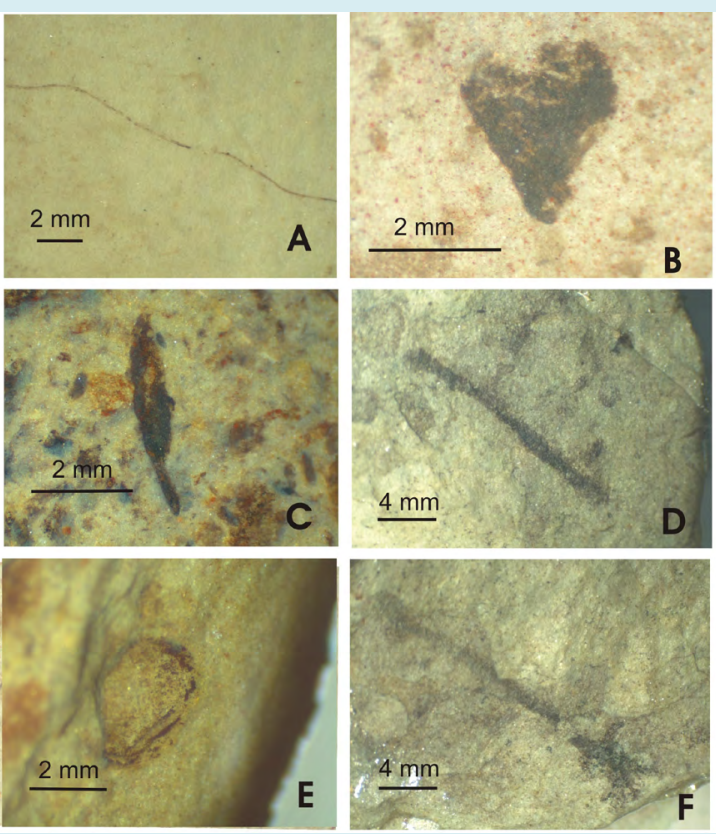

Figure 5: Carbonaceous megafossils from the Samria Shale in Rajwas village, Bundi district, Rajasthan.

(A) Proterotainia montana, thread like thin filament, Sample No. Rj-w $(25 \mathrm{x} 4)$.

(B) Eopalmaria prinstina with tapered base deflated upper part and median depression, Sample No.Rj-14 (25x3).

(C) Changchengia stipitata/ Tuanshanzia lanceolata with elongated body tapering at both ends, Sample No. Rjb1 $(25 \times 4)$.

(D) -cf. Vendotaenia, thick filamentous sheath like structures of almost uniform width and without rounded ends, a hold fast like structure is seen in F, Sample No Rj-t (25x3.5) for both photographs.

(E) Balloon shaped body assignable to longfengshania sp. except the absence of stipe, Sample No. Rj-s (25x4).

(F) -cf. Vendotaenia, thick filamentous sheath like structures of almost uniform width and without rounded ends, a hold fast like structure is seen in F, Sample No Rj-t (25x3.5) for both photographs.

Specimens exhibiting oval to lanceolate or oval to cuneiform sheet like that, sometimes depression at median part of rounded end giving it a forked structure, tapered at the base, resemble to some extent with Eopalmaria prinstina (Figure 3A; Figure 5B): a form considered to be multicellular megascopic algae. Length varies between $3-6 \mathrm{~mm}$; width varies between $1.5-3 \mathrm{~mm}$ ( 7 specimens).

Number of fossils reported in present assemblage are comparable to forms reported from the Koldaha Shales of Lower Vindhyans $[10,11]$, and multicellular carbonaceous 


\section{International Journal of Paleobiology \& Paleontology}

fossils from China [12]. Carbonaceous fossils with lanceolate, sheet like structure tapered at both the ends, with or without parastem are assignable to Changchengia stipitata or Tuanshanzia lanceolata, both are considered synonyms (Figure 5- C) as described by Liu, et al. [13]. These forms acquire maximum width in middle part $1.5 \mathrm{~mm}$; length varies between $2-4 \mathrm{~mm}$ (4 specimens). Apex or apical part exhibits little truncation. As far as affinity of this form is concerned it is still debatable. Few consider it as Chlorophycean and others favor its phaeophycean (brown algal) affinity.

Carbonaceous fossils acquiring elliptical shape with or without wrinkles and folds are assignable to Ellipsophysa. Length varies between $2-6 \mathrm{~mm}$; width varies between. $50-3.0 \mathrm{~mm}$ (20 specimens) they can also be considered as deformed Chuaria (Figure 4C-D). Smooth, three dimensional very thin filaments or strings of almost uniform width of $3 \mathrm{~mm}$ are assignable to Proterotainia montana (Figure 5A). Irregular filamentous fragments are also present which are difficult to assign any taxonomic position. Thick filamentous sheath like carbonaceous films (Figure 5D,F) with root or hold fast like structure in one specimen (Figure 5F) indicate them to be attached benthic forms. Width ranges between $1-2 \mathrm{~mm}$, length ranges between $3.5-5 \mathrm{~mm}$ ( 4 specimens). A form exhibiting ellipsoidal balloon shaped body gives some resemblance with Longfengshania sp., except the absence of stipe or string (Figure 5E). Length varies between 2-3mm, width ranges between $1.5-3.5 \mathrm{~mm}$ ( 2 specimens).

A sheath like structure encompassing numerous small cell like units is comparable to multicellular tissue of a metaphyte (Figure 3F). Presence of tissues in Precambrian carbonaceous compressions is very rare. They have been reported only from the phosphorites and siliceous rocks of few places like 900Ma old Bangiophyte colonies from the Somerset Island in northern Canada and Doushantuo Formation of southern China. As stated by Zhang, et al. [13], multicellular Non-vascular plants evolved long before the appearance of vascular plants. The form is preserved as kerogenous remains of algal thalli with cellular tissues.

A single specimen exhibiting cylindrical or cone like body with prominent elliptical cross section comprises a prominent ring like structure and a flap/loop like string of $2.5 \mathrm{~mm}$ length. It is difficult to determine the affinity as well as identity of this form, whether belonging to a plant or animal. It is therefore placed among unidentified form ' $\mathrm{A}$ ' (Figure 4B).

A single specimen exhibiting peculiar morphology is also very difficult to assign the taxonomic position. It has an elongated body of $7 \mathrm{~mm}$ and width of $2.5 \mathrm{~mm}$, with an opening like structure at broader end and a faint hold fast like structure at the tapered end. A median gut like structure of $1.5 \mathrm{~mm}$ width is running along its whole length. As far as affinity of this form is concerned it is very difficult to decide whether it belongs to an animal or a plant kingdom. There is a possibility that this particular form represents a metazoan (animal affinity). An opening like structure may be its mouth. Among Xanthophycean algae, Vaucheria is the nearest analogue for this specimen. There is one more possibility that it can be a benthic plant body with a hold fast like structure. Since affinity and identity of this form is dubious, it is also described here as unidentified form 'B'.

\section{Affinity}

Hofmann, et al. [14] related Tawuia to the group Vendotaenidae and inferred that it could be either brown algae (Phaeophyta) or a metazoan. It was also suggested that Chuaria and Tawuia could be eukaryotic algae and possibly represent an alternation of generation of the same organisms [15]. Considered Chuaria and Tawuia as multicellular algae and suggested that Tawuia can be related to Chuaria through the intermediate oval form as a morphological variant in the process of evolution. He placed both forms under family Chuariaceae and related them with forms of Vendotaenia.

It was inferred that Tawuia was originally soft resilient elongate and cylindrical body enclosed within a thin smooth and firm outer membrane or sheath [14]. Tiny circular bodies including terminal disc in an elongate Tawuia like structure and small spherical bodies in Chuaria like vesicle [16,17], can be considered daughter colonies. It is also an evidence for the relationship between them.

Vendotaenids are also elongated bodies, but an irregular shape and twisted or folded structure with rounded ends [18]. Inferred that Vendotaenids are multicellular alga, possibly a brown alga with longitudinally arranged circular cells or sporangia.

\section{Conclusion}

Pyritized Chuarids (and a Tawuia) with equally good morphological preservation indicate presence of resistant vesicle and excystment structures suggesting their eukaryotic affinity [8]. Pyritized Chuaria and Tawuia occur in certain geochemical conditions. Iron sulphide covers or replaces entire organism, resulting into fossils with gold like lustier [19-24]. Pyritization also indicates rapid burial of organism in ocean sediments, which is low in both organic material and decaying material (bacteria) in anaerobic condition like very low amount of dissolved oxygen. Carbonaceous megafossils of the Samria Shale represent an advanced assemblage comprising multicellular algal forms of variable affinities and a form possibly of an animal affinity (?). Presence of Chuaria-Tawuia and a number of multicellular carbonaceous 


\section{International Journal of Paleobiology \& Paleontology}

megafossils are potential chrono-bio-stratigraphic markers. The pre-Ediacaran radiation of phytoplanktons with a possible metazoan can be considered as the most conspicuous biotic event of the Vindhyan Super group [25-27].

\section{Acknowledgements}

Author is indebted to Head, Department of Geology, Lucknow University, and Lucknow, India for providing basic facilities to carry out the present work. Financial assistance for Field work received from DST (WOS Project) is thankfully acknowledged.

\section{References}

1. Heron AM (1936) The Geology of south eastern Mewar, Rajputana. Mem Geol Surv India 68: 1-20.

2. Prasad B (1984) Geology, sedimentation and palaeogeography of the Vindhyan Super group, Southeastern Rajasthan. Mem Geol Surv India 116(1): 1-107.

3. Hofmann HJ (1985) Precambrian carbonaceous megafossils. In: Toomy DF, et al. [Eds.], Palaeoalgology: Contemporary Research and Application, SpringerVerlag, Berlin.

4. Srivastava P (2006) Possible Ediacaran fossils from the Bundi Hill Sandstone, Upper Vindhyans, (Abst) Rajasthan. Diamond Jubilee International Conference on Changing Scenario in Palaeobotany and allied subjects, Lucknow, pp: 188.

5. Kumar S (2001) Meso-Proterozoic megafossil ChuariaTawuia association may represent parts of a multicellular plant, Vindhyan Super group, Central India. Precambrian Research 106(3-4): 187-211.

6. Kumar S, Srivastava P (1997) A note on the carbonaceous megafossils from the Neoproterozoic Bhander Group, Maihar area, M. P. J Pal Soc India 42: 141-146.

7. Sun W (1987) Palaeontology and Biostratigraphy of late Precambrian macroscopic colonial algae: Chuaria Walcott and Tawuia Hofmann. Palaeontographica Abteilung B Band 4(6): 109-133.

8. Xunlai Y, Shuai X, Li J, Yin L, Cao R (2001) Pyritized chuarids with excystment structures from the late Neoproterozoic Lantian formation in Anhui, South China. Precambrian Research 107(3-4): 253-263.

9. Zhu M, Babcock LE, Steiner M (2005) Fossilization modes in the Chengjiang Lagerstätte (Cambrian of China): Testing the roles of organic preservation and diagenetic alteration in exceptional preservation. Palaeogeography Palaeoclimatology Palaeoecology 220(1-2): 31-46.
10. Sharma M (2006) Late Palaeoproterozoic (Statherian) carbonaceous films from the Olive Shale (Koldaha Shale), Semri Group, Vindhyan Super group, India. J Palaeontol Soc India 51(2): 27-35.

11. Rai V, Singh VK (2006) Discovery of megascopic multicellularity in deep time: New evidences from $\sim 1.63$ billion years old Lower Vindhyan succession, Vindhyan Supergroup, Uttar Pradesh, India. J Appl Biosci 32(2): 196-203.

12. Shixing Z, Shufen S, Xuenguan H, Yuzhen H (2000) Discovery of carbonaceous compressions and their multicellularity tissues from the Changzhougou Formation (1800Ma) in the Yanshan range, North China. Chinese Sci Bull 45: 841-847.

13. Yan Y, Liu Z (1997) Tuanshanzian macroscopic algae of $1700 \mathrm{Ma}$ b. p. from Changcheng System of Jixian, China. Acta Palaeontologica Sinica 36: 18-41.

14. Hofmann HJ, Aitken JD (1979) Precambrian Biota from the Little Dal Group, Mackenzie Mountains, northwest Canada. Canad Jour Eart Sci 16(1): 150-166.

15. Hofmann HJ (1981) Precambrian Fossils in CanadaThe 1970's in retrospect. In: Campbell FHA (Eds.), Proterozoic Basins of Canada. Geol Surv, Canada 81(10): 443-447.

16. Wenwu Z (1980) A new occurrence of fossil group Chuaria from the Sinian System in north Anhui and its geological meaning. Bull Tianjin Inst Geol Min Res 1(1): 49-69.

17. Kumar S, Srivastava P (2003) Carbonaceous megafossils from the Neoproterozoic Bhander Group, Central India. Palaeontol Soc India 48: 139-154.

18. Gnilovskaya MB (1983) Vendotaenids. In: Urbanek A, et al. (Eds.), Upper Precambrian and Cambrian Paleontology of the east European Platform. Publishing House of Wydawnictwe Geologiczne, Warszawa, pp: 4655.

19. Ping CY, Hong H (2007) Pyritization in the Gaojiashan Biota. Chinese Science Bulletin 52: 645-650.

20. Srivastava P (2002) Carbonaceous megafossils from the Dholpura Shale, Uppermost Vindhyan Supergroup, Rajasthan: An age implication. J Palaeontol Soc India 47: 97-105.

21. Srivastava P (2004) Carbonaceous fossils from the Panna Shale, Rewa Group (Upper Vindhyans), Central India: A possible link between evolutions from Micromegascopic life. Current Science 86(5): 644-646.

22. Srivastava P, Bali R (2006) Proterozoic Carbonaceous 


\section{International Journal of Paleobiology \& Paleontology}

remains from the Chorhat Sandstone: oldest fossils of the Vindhyan Super group, Central India. Geobios 39(6): 873- 878 .

23. Srivastava P (2011) Unidentified complex morphologies among the fossils of the Vindhyan Supergroup, indicating an advanced Ecosystem. Arabian J Earth Sci, pp: 1-12.

24. Srivastava P, Tewari VC (2011) Morphological Changes in micro-megascopic life during late PalaeoproterozoicNeoproterozoic transition: The Vindhyan Super group, India. Springer.

25. Srivastava P (2012) Morphodiversity, complexity and macroevolution: Revealed by the megascopic life of the Palaeo-Neoproterozoic Vindhyan Super group, India. Geological Society Publications 365: 247-262.

26. Sharma M, Kumar S, Tewari M, Shukla Y, Pandey SK, et al. (2012) Palaeobiological Constraints and the Precambrian Biosphere: India Evidence. Proc Indian Nat Sci Acad 78(3): 407-422.

27. Stefan B (1994) Early life on Earth: Nobel Symposium, 84. Columbia University Press, New York, pp: 656. 